\title{
Interdecadal Changes in the Freeze Depth and Period of Frozen Soil on the Three Rivers Source Region in China from 1960 to 2014
}

\author{
Siqiong Luo, ${ }^{1}$ Xuewei Fang, ${ }^{1}$ Shihua Lyu, ${ }^{2}$ Qi Jiang, ${ }^{2}$ and Jingyuan Wang ${ }^{1}$ \\ ${ }^{1}$ Key Laboratory of Land Surface Process and Climate Change in Cold and Arid Regions, \\ Northwest Institute of Eco-Environment and Resources, Chinese Academy of Sciences, Lanzhou 730000, China \\ ${ }^{2}$ School of Atmospheric Sciences, Plateau Atmosphere and Environment Key Laboratory of Sichuan Province, \\ Chengdu University of Information Technology, Chengdu 610225, China \\ Correspondence should be addressed to Siqiong Luo; lsq@lzb.ac.cn
}

Received 31 October 2016; Revised 23 January 2017; Accepted 28 February 2017; Published 19 March 2017

Academic Editor: Anthony R. Lupo

Copyright (C) 2017 Siqiong Luo et al. This is an open access article distributed under the Creative Commons Attribution License, which permits unrestricted use, distribution, and reproduction in any medium, provided the original work is properly cited.

\begin{abstract}
On the basis of observed soil freeze depth data from 14 meteorological stations on the Three Rivers Source Region (TRSR) in China during 1960 to 2014, trends in the freeze depth, first date, last date, and duration of frozen soil were analyzed, together with other meteorological variables, such as air temperature, snow depth, and precipitation, observed at the same locations. The results showed the following. (1) A continuous, accelerated decreasing trend in freeze depth appeared in the TRSR during the 1985-2014 and 2000-2014 periods, compared with that during the 1960-2014 period. (2) The freeze first date had been delayed and the freeze last date had been advanced significantly. The advanced trends in freeze last date were more significant than the delayed trends in freeze first date. The freeze duration also experienced an accelerated decrease. (3) The freeze depth and period were strongly affected by air temperature, thawing index, and soil moisture (precipitation), but not by snow. The freeze depth, freeze first date, freeze last date, and duration also influenced each other. (4) These decreasing trends in freeze depth and duration are expected to continue given the increasing trends in air temperature and precipitation in this region.
\end{abstract}

\section{Introduction}

Frozen soil is a sensitive indicator of climate change. It is highly correlated with air temperature [1-3]. Both observational and modelling studies indicate that frozen soil conditions are currently rapidly changing in response to global warming. Soil temperature has continued to rise over the past several decades $[1,4,5]$; areas of permafrost and seasonal frozen soil have decreased [6-8]; the active layer has become much thicker [9-12]; and landscapes have changed [13-15]. This deterioration in frozen soil will have profound effects on energy and hydrological cycles through accelerating the decomposition of organic carbon in the soil and increasing the release of $\mathrm{CO}_{2}$ from the soil to the atmosphere, altering terrestrial ecosystems and thereby creating a positive feedback loop leading to further climate change [16-21].

The freeze depth and period (including freeze first date, freeze last date, and duration) of frozen soil, which are strongly affected by air temperature, snow, soil moisture, and vegetation [22-26], are important indexes of frozen soil conditions. The interdecadal changes in these along with variations in climatic variables at local and regional scales are still relatively poorly understood. A major obstacle to understanding the response of frozen soil to climate change, as well as the interactions between the soil and the atmosphere, is the lack of long-term observations. For this reason, other climatic indicators, such as soil temperature and minimum air temperature, remote sensing data, and numerical simulation, are exploited to characterize the freeze depth and period of frozen soil. Frauenfeld et al. [27] employed a linear interpolation method to determine the depth of the $0^{\circ} \mathrm{C}$ isotherm based on soil temperature data measured between $0.2 \mathrm{~m}$ and $3.2 \mathrm{~m}$ depth, using mean monthly soil temperature data collected between 1930 and 1990 from 242 stations located throughout Russia. They found that the active layer of permafrost increased by $20 \mathrm{~cm}$ and the depth of the seasonal 


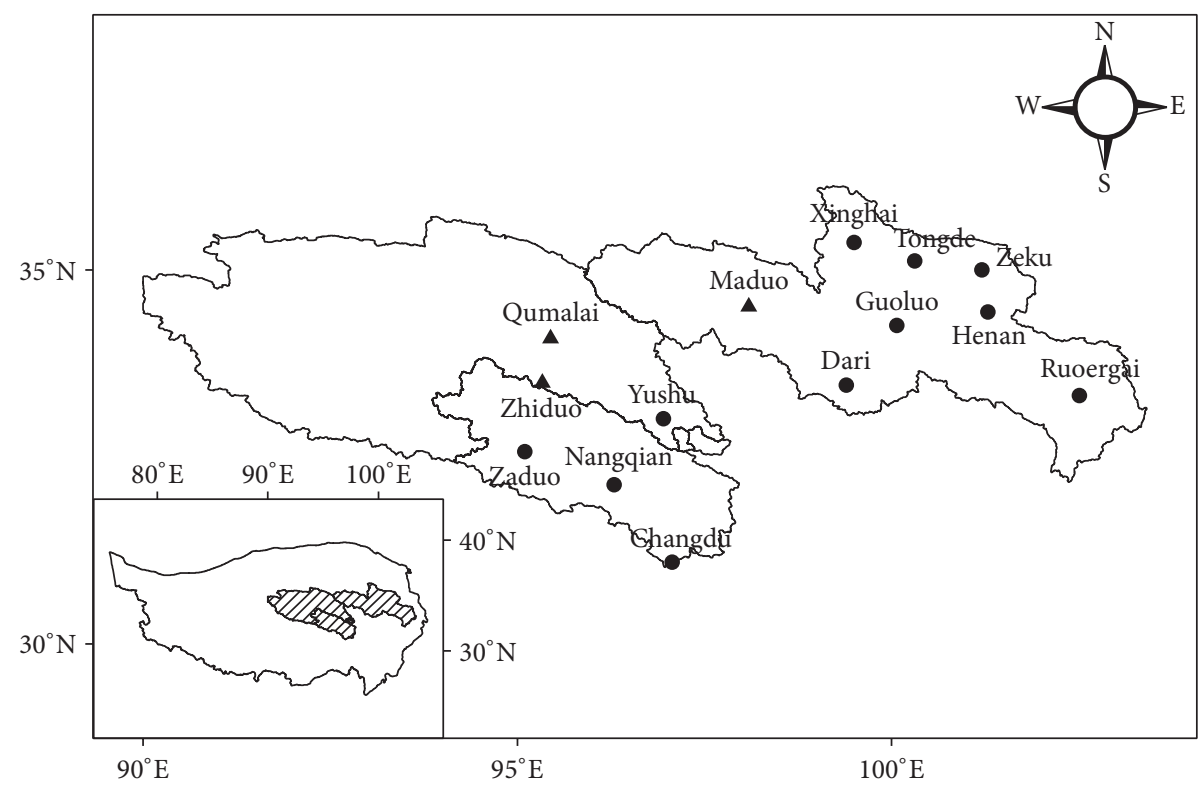

FIGURE 1: Study area and locations of the meteorological stations in the Three Rivers Source Region (TRSR) of the Tibetan Plateau (TP). Black circles reflect data availability from 1960 to 2014, and black triangles reflect data availability from 1985 to 2014.

frozen soil decreased by $34 \mathrm{~cm}$ between 1956 and 1990 . Anandhi et al. [28] and Wang et al. [25] calculated the freeze first date, freeze last date, and duration of the soil frost period based on daily minimum air temperatures in Kansas, USA, and in China. Their results all indicated that the freeze first date was delayed and the last date was advanced over their study period. Using Special Sensor Microwave/Imager (SSMI) data on the Tibetan Plateau (TP), Li et al. [29] discovered a trend towards a later onset date of soil freeze by approximately 10 days and an earlier onset date of soil thaw by approximately 14 days over the period 1988-2007. Recently, numerical simulations have been used to investigate the changes in the near-surface soil freeze-thaw cycle in response to the warming on the TP from 1981 to 2010 [24]. Similar results have been found elsewhere. It should be noted, however, that although the $0^{\circ} \mathrm{C}$ isotherm and minimum air temperature can be used as an estimate of the freeze depth and period of soil; they are not the same as the "true" value. While remote sensing data and numerical simulations can analyze the spatial variations, the long-term interdecadal variation fractures cannot be shown due to data shortage.

The Three Rivers Source Region (TRSR) is located where China's two longest rivers, the Yangtze and Yellow Rivers, and a transnational river, the Mekong River (called Lancang in China), originate. It located in the northeastern TP which is a mosaicked transitional zone of seasonal frozen soil and discontinuous and continuous permafrost [30,31]. This region is particularly sensitive to the impacts of climate change $[4,32-$ 36]. One robust observation is that air temperatures in this region have been rising by an average rate of $0.32-0.36^{\circ} \mathrm{C}$ decade $^{-1}$ over the past half century (from 1960 to 2010) [33, 35 , while the average rate is determined to be even greater when measured over the last 35 years $\left(0.46^{\circ} \mathrm{C}\right.$ decade $^{-1}$ between 1980 and 2014) [4]. This warming is more rapid than the average values experienced over the same time period on the TP and China [37-41]. In this study, we used observed soil freeze depth data obtained from meteorological stations to investigate the interdecadal changes in the freeze depth and period in the TRSR, from 1960 to 2014. Using the data from 14 stations, we analyzed trends in the freeze depth and freeze period (including first date, last date, and duration) of frozen soil and examined their relationships to air temperature, thawing index, snow depth, and precipitation, as well as each other.

\section{Data and Methods}

The basic data used in this study include the observed freeze depth of the soil, air temperature, snow depth, and precipitation. The data were available for 14 meteorological stations located throughout TRSR (Figure 1). Including 11 meteorological stations for 55 years (from 1960 to 2014) and three meteorological stations for 30 years (from 1980 to 2014). All of the data were collected daily at these stations, which are located in the seasonal frozen soil area. A list of the stations is provided in Table 1, and the locations of the stations are shown in Figure 1. The freeze depth of the soil was observed once per day (08:00 h Beijing Time) using a frozen soil apparatus when the ground surface temperature was below $0^{\circ} \mathrm{C}[42]$. Generally, the frozen soil apparatus was placed in the natural land cover in the observation field [42]. Land cover of observation field in these meteorological stations was typical alpine meadow, with canopy height no more than $0.20 \mathrm{~m}$ in summer and no more than $0.05 \mathrm{~m}$ in winter (Figure 2). Frozen soil apparatus consisted of two major tubes: outer tube and inside tube. The inside tube was rubber tube with clean water. The soil freeze depth was defined by the water freeze depth in inside tube [42]. The maximum freeze 
TABLE 1: Details of the meteorological stations.

\begin{tabular}{|c|c|c|c|c|c|}
\hline Station & Number & Latitude $\left({ }^{\circ} \mathrm{N}\right)$ & Longitude $\left({ }^{\circ} \mathrm{E}\right)$ & Height (m) & Data period \\
\hline Xinghai & 52943 & $35^{\circ} 35^{\prime}$ & $99^{\circ} 59^{\prime}$ & 3323 & 1960-2014 \\
\hline Tongde & 52957 & $35^{\circ} 16^{\prime}$ & $100^{\circ} 39^{\prime}$ & 3289 & 1960-2014 \\
\hline Zeku & 52968 & $35^{\circ} 02^{\prime}$ & $101^{\circ} 28^{\prime}$ & 3663 & 1960-2014 \\
\hline Zaduo & 56018 & $32^{\circ} 54^{\prime}$ & $95^{\circ} 18^{\prime}$ & 4066 & 1960-2014 \\
\hline Yushu & 56029 & $33^{\circ} 01^{\prime}$ & $97^{\circ} 01^{\prime}$ & 3681 & $1960-2014$ \\
\hline Guoluo & 56043 & $34^{\circ} 28^{\prime}$ & $100^{\circ} 15^{\prime}$ & 3719 & $1960-2014$ \\
\hline Dari & 56046 & $33^{\circ} 45^{\prime}$ & $99^{\circ} 39^{\prime}$ & 3968 & 1960-2014 \\
\hline Henan & 56065 & $34^{\circ} 44^{\prime}$ & $101^{\circ} 36^{\prime}$ & 3500 & 1960-2014 \\
\hline Ruoergai & 56079 & $33^{\circ} 35^{\prime}$ & $102^{\circ} 58^{\prime}$ & 3440 & 1960-2014 \\
\hline Nangqian & 56125 & $32^{\circ} 12^{\prime}$ & $96^{\circ} 29^{\prime}$ & 3644 & $1960-2014$ \\
\hline Changdu & 56137 & $31^{\circ} 09^{\prime}$ & $97^{\circ} 10^{\prime}$ & 3306 & $1960-2014$ \\
\hline Zhiduo & 56016 & $33^{\circ} 51^{\prime}$ & $95^{\circ} 36^{\prime}$ & 4179 & 1985-2014 \\
\hline Qumalai & 56021 & $34^{\circ} 08^{\prime}$ & $95^{\circ} 47^{\prime}$ & 4175 & $1985-2014$ \\
\hline Maduo & 56033 & $34^{\circ} 55^{\prime}$ & $98^{\circ} 13^{\prime}$ & 4272 & $1985-2014$ \\
\hline
\end{tabular}

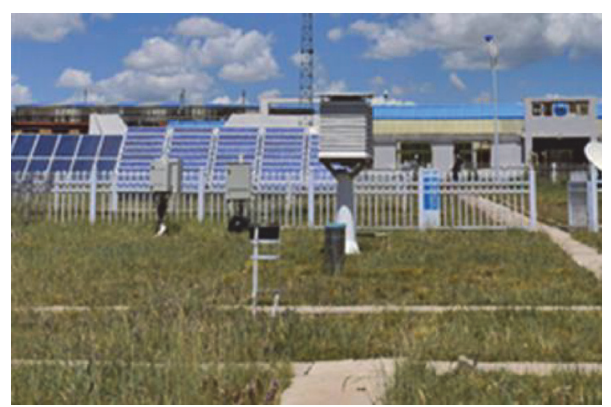

(a)

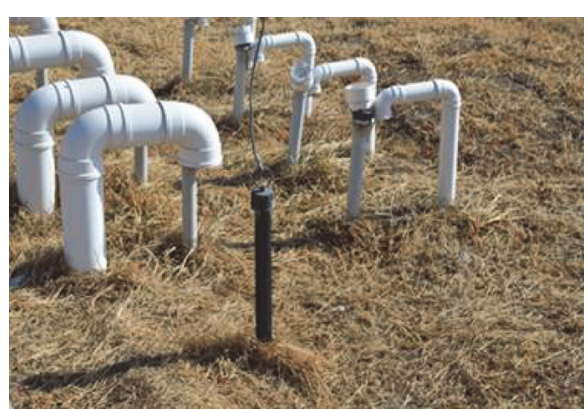

(b)

FIGURE 2: Land cover of observation field in meteorological stations. (a) Summer; (b) Winter.

depth was selected from all daily freeze depth data for each year to represent annual freeze depth. The data were reported when the freeze depth exceeded the maximum range of the frozen soil apparatus in original data. The freeze depth in that year was not included in this study. The snow depth was observed once per day (08:00 h Beijing Time) using a snow scale when snow cover was more than 0.5 . The data is based on the average of three measurements [42]. In order to cover the entire period with potential freezing events, annual values of the freeze first date, freeze last date, and freeze duration were calculated for each year beginning on 1 September of the preceding year, and ending on 31 August of the current year, when the freeze depth did not equal zero.

For this study, line trends were used in Matlab (MathWorks) to detect trends in the freeze depth, first date, last date, and duration of frozen soil. Line trends were also used to detect trends in other climate variables, including air temperature, thawing index, maximum snow depth, annual precipitation, spring (March, April, and May) precipitation, summer (June, July, and August) precipitation, and autumn (September, October, and November) precipitation at the same locations. Previous studies have shown significant abrupt changes in freeze depth in the mid-1980s and 1999 on the TP $[43,44]$. A recent study also showed that an accelerated warming trend appeared over the TP during the 1998-2013 period in comparison with the 1980-1997 period [39]. In this study, 1985 and 2000 were chosen as the points in time when interdecadal variations could reliably be assessed. Therefore, variations were broken down into three different time periods: from 1960 to 2014 (the last 55 years), from 1985 to 2014 (the last 30 years), and from 2000 to 2014 (the last 15 years). Correlation analysis, which is a commonly used method of statistical diagnosis in modern climatic analysis studies [45], was used to identify relationships between the freeze depth, first date, last date, and duration of frozen soil with other climate variables. In order to cover the entire period with potential freezing events, the correlation between first freeze date, last date, and duration with other forcing variables was all calculated for each year beginning on 1 September of the preceding year and ending on 31 August of the current year. The thawing index TI is the sum of the average air temperatures $\mathrm{Ti}$ based on monthly data when air temperature is above freezing; that is, for $i=1,2, \ldots, N$,

$$
T I=\sum_{i=1}^{N} T i, \quad T i>0^{\circ} \mathrm{C} .
$$




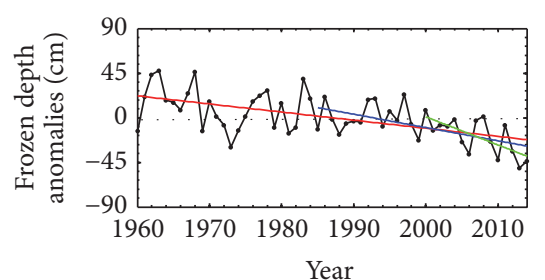

(a)

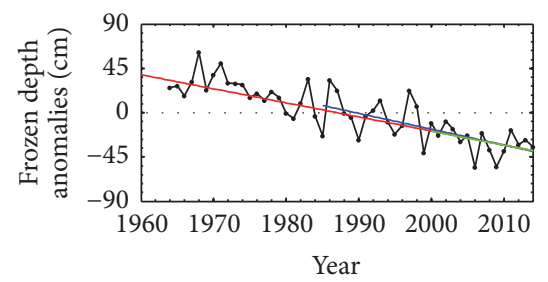

(d)

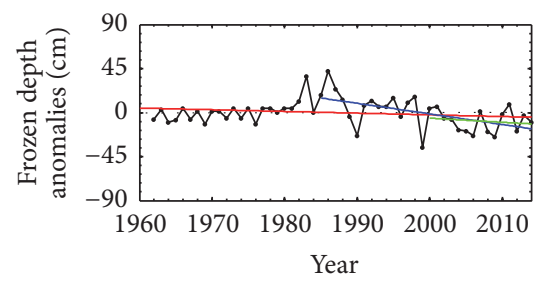

(g)

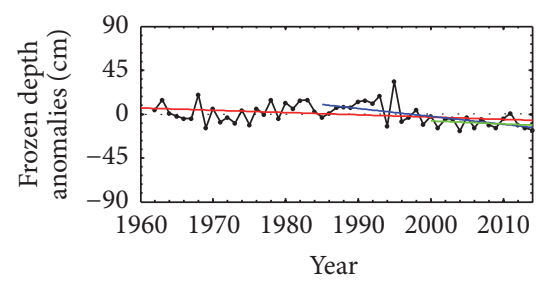

(j)

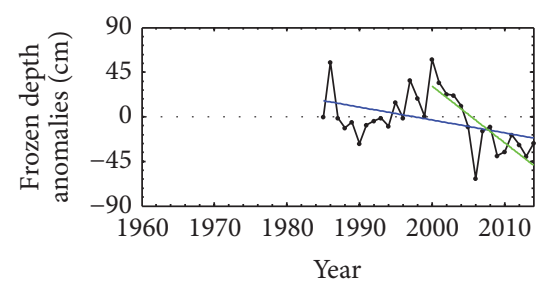

(m)

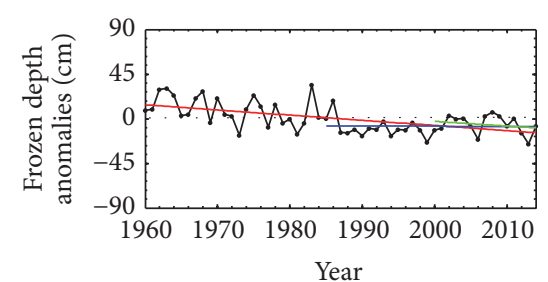

(b)

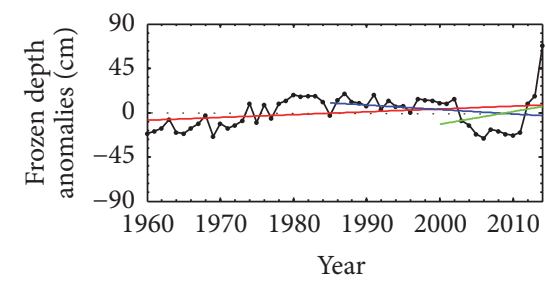

(e)

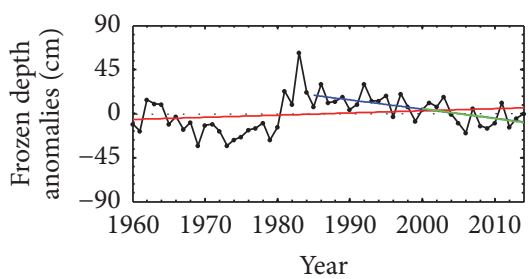

(h)

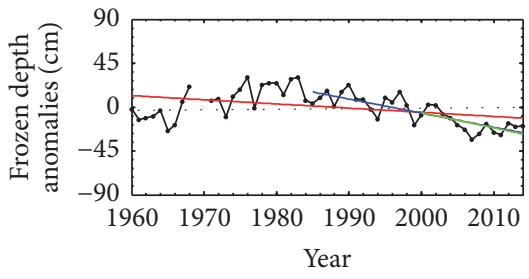

(k)

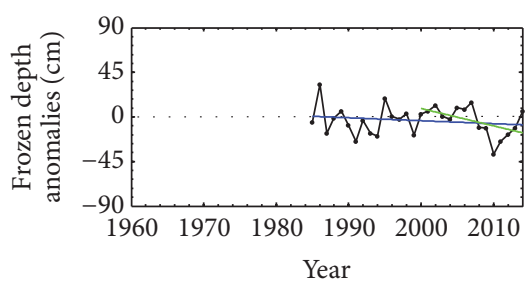

(n)

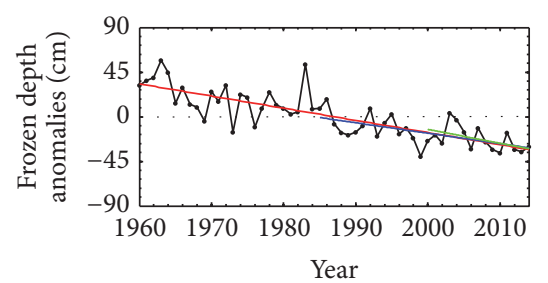

(c)

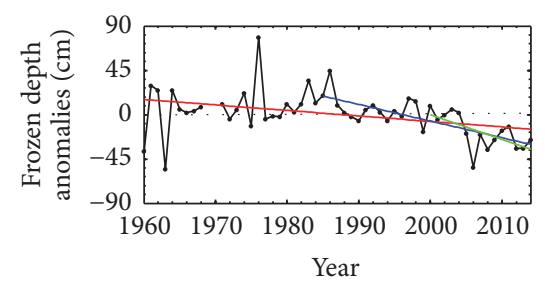

(f)

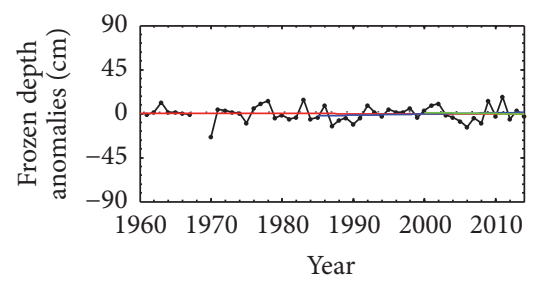

(i)

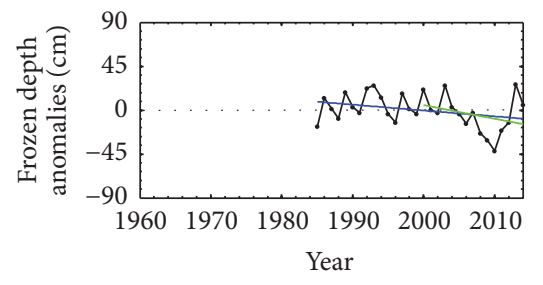

(l)

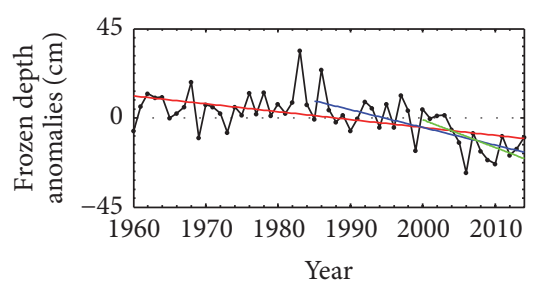

(o)

FIGURE 3: Freeze depth anomaly series during 1960-2014. Linear least squares regression lines are included for 1960-2014 (red line), 1985-2014 (blue line), and 2000-2014 (green line). (a) Xinghai station, (b) Tongde station, (c) Zeku station, (d) Zaduo station, (e) Yushu station, (f) Guoluo station, (g) Dari station, (h) Henan station, (i) Ruoergai station, (j) Nangqian station, (k) Changdu station, (l) Zhiduo station, (m) Qumalai station, (n) Maduo station, and (o) average.

\section{Results}

3.1. Changes in the Soil Freeze Depth. Table 2 and Figure 3 indicate the trends in freeze depth on the TRSR during 1960-2014. The freeze depth exhibited a statistically significant decrease (at $\alpha=0.01$ ) during 1960-2014, 1985-2014, and 2000-2014 on the TRSR. The soil freeze depth decreased at 10 stations, while it increased only marginally at one station (Yushu), with an average value of $-3.98 \mathrm{~cm} \mathrm{decade} \mathrm{e}^{-1}$ over the past 55 years. Over the past 30 years, a decreasing trend occurred in 13 stations, while one station (Ruoergai) increased only marginally with an average value of $-8.93 \mathrm{~cm}$ decade $^{-1}$. This result was similar to but slightly below that of our previous study where $-10.61 \mathrm{~cm}$ decade ${ }^{-1}$ was recorded by modified Mann-Kendall trend test and Sen's slope estimator from the observation data of nine meteorology stations over the last 35 years (1980-2014) [4]. Decreasing trends also occurred in 13 stations over the last 15 years, with an 


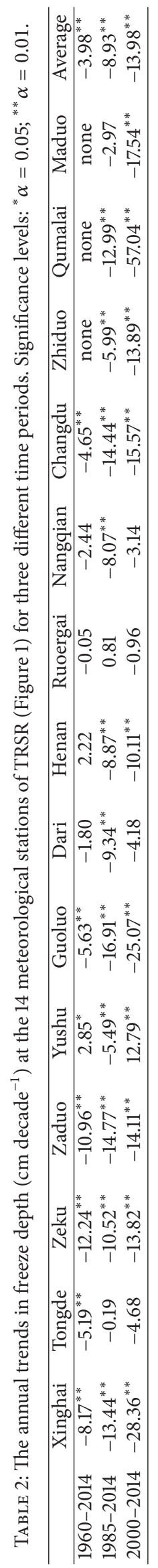


average rate of $-13.98 \mathrm{~cm}$ decade ${ }^{-1}$. There were only two significant increases recorded (at $\alpha=0.05$ ). These occurred at Yushu station during 1960-2014 and during 2000-2014, at rates of 2.85 and $12.79 \mathrm{~cm}$ decade $^{-1}$, respectively. The overall decreasing trends indicated that, in areas of seasonal frozen soil, the soil was freezing to increasingly shallower depths each year. Furthermore, a continuously accelerated decreasing trend had appeared in the TRSR during the 1985-2014 and 2000-2014 periods, compared with the $1960-2014$ period. The net change was a $21.89 \mathrm{~cm}$ decrease in freeze depth in 2014 compared to 1955, and an even greater decrease of $26.79 \mathrm{~cm}$ from 1985 to 2014, while a decrease of $20.97 \mathrm{~cm}$ was recorded over the past 15 years.

3.2. Changes in the Soil Freeze Period. Table 3 and Figure 4 show the trends observed in the freeze first date, freeze last date, and freeze duration on the TRSR during the study period. The first freeze date experienced a significant delay over the past 55 years, where it has been delayed at 10 stations at an average rate of 3.20 days decade ${ }^{-1}$. Over the past 30 years, this delayed trend occurred in 13 stations at an average rate of 5.65 days decade ${ }^{-1}$. Over the past 15 years, the delayed trend occurred in 10 stations, with an average rate of 9.11 days decade ${ }^{-1}$. There were only 2 significant advances in first freeze date (at $\alpha=0.05$ ), observed at Maduo station during 1985-2014 and at Changdu station during 2000-2014, at rates of -5.91 and -5.68 days decade $^{-1}$, respectively. These trends in freeze first date indicated that, on the TRSR, the soil was freezing later and later each year, and an accelerated increasing trend had appeared in the region during 2000-2014, compared with that during 1985-2014 and 1960-2014. The net change was a 17.60-day delay in freeze first date in 2014 compared to 1955; a 16.95-day delay from 1985 to 2014; and a 13.67-day delay from 1985 to 2014.

According to Table 3, the freeze last date advanced at all stations over the past 55 years, and this trend was found to be significant in eight stations (at $\alpha=0.05$ ) with an average rate of -3.55 days decade ${ }^{-1}$. Over the last 30 years, a significantly advanced trend (at $\alpha=0.05$ ) was observed in 13 stations with an average rate of -9.42 days decade ${ }^{-1}$. Over the last 15 years, a significantly advanced trend (at $\alpha=0.05$ ) occurred in 8 stations at an average rate of -10.64 days decade ${ }^{-1}$. The net change was a 19.53-day advance in last freeze date in 2014 compared to 1955, and an even greater increase of 28.26 days between 1985 and 2014. Between 1985 and 2014, this value was 15.96 days. The advanced trend in last freeze date was more significant than the delayed trend in first freeze date across all three study periods.

Based on the above data, the freeze duration decreased significantly during the 1960-2014, 1985-2014, and 2000-2014 periods. The trends in freeze duration date ranged from -16.21 to -2.65 days decade ${ }^{-1}$, with an average value of -7.52 day decade ${ }^{-1}$ over the past 55 years. The significantly decreasing trend (at $\alpha=0.01$ ) occurred in 13 stations at an average rate of -14.74 days decade ${ }^{-1}$ over the past 30 years. Over the past 15 years, a significantly decreasing trend (at $\alpha=0.01$ ) occurred in 12 stations at an average rate of -16.90 days decade ${ }^{-1}$. There was only one significant increase in freeze duration (at $\alpha=0.01$ ), observed at Changdu station during 2000-2014, at rates of 11.39 days decade ${ }^{-1}$. These decreasing trends also indicate that, in areas of seasonally frozen soil, the soil remains frozen for fewer days each year, and an accelerated decreasing trend of freeze duration had appeared in the TRSR during the 1985-2014 and 2000-2014 periods, compared with the 1960-2014 period. The net change was a 41.36-day decrease in freeze duration in 2014 compared to 1955 and an even greater 44.22-day decrease from 1985 to 2014, while a decline of 25.35 days was observed over the past 15 years.

\section{Discussion}

4.1. Changes in the Forcing Variables. The freeze depth and period are strongly affected by external forcing variables, such as air temperature [24, 25], snow [27], and vegetation [23, 26]. They are also associated with soil hydrology and thermal conditions $[20,21,26]$. Soil moisture, which is significantly associated with freeze depth and period, has not been investigated as much as other climate variables, such as air temperature and precipitation, because the data are not widely available for either spatial or temporal coverage. In general, changes in precipitation correspond well to changes in soil moisture. For this reason, changes in precipitation have been exploited to characterize the changes in soil moisture [46]. In this study, to explore the potential causes for the observed trends in freeze depth and period since 1960, the averaged time series were related to mean annual air temperature, thawing index, maximum snow depth, and annual, spring, summer, and autumn precipitation.

As indicated in Table 4, air temperature and thawing indexes increased significantly (at $\alpha=0.01$ ) in all three study periods. Over the past 55 years, the average trend in air temperature corresponded to a $0.30^{\circ} \mathrm{C}$ increase decade ${ }^{-1}$. This trend was relatively similar to previous studies that recorded an increasing trend of $0.32-0.34^{\circ} \mathrm{C}$ decade $^{-1}$ from observation data during 1960-2010 [33, 35]. The trend in air temperature during $1985-2014$ (average rate: $0.62^{\circ} \mathrm{C}$ decade $^{-1}$ ) was even greater than that during $2000-2014\left(0.61^{\circ} \mathrm{C}\right.$ decade $\left.^{-1}\right)$. These two trends were all larger than the $0.46^{\circ} \mathrm{C}$ decade ${ }^{-1}$ recorded from 1980 to 2014 in this region [4], implying that a significant accelerated warming trend had appeared over the TRSR since 1985. An accelerated increasing trend in thawing index also appeared during 2000-2014 (average rate: $3.83^{\circ} \mathrm{C} \cdot$ month decade $\left.{ }^{-1}\right)$, compared with that during 1985-2014 $\left(3.60^{\circ} \mathrm{C} \cdot\right.$ month decade $\left.{ }^{-1}\right)$ and during 1960-2014 $\left(1.56^{\circ} \mathrm{C} \cdot\right.$ month decade $\left.{ }^{-1}\right)$. The change in maximum snow depth was not significantly different between all three study periods. Positive trends in annual precipitation were detected in all periods, but only one clear increasing trend was observed during the past 15 years $\left(62.82 \mathrm{~mm} \mathrm{decade}^{-1}\right)$. The precipitation in spring, summer, and autumn also displayed increasing trends in the three study periods. Significant increasing trends occurred in spring during 1960-2014 and during 2000-2014, at rates of 1.64 and $17.43 \mathrm{~mm} \mathrm{decade}^{-1}$, respectively. The linear trends in snow and precipitation were 


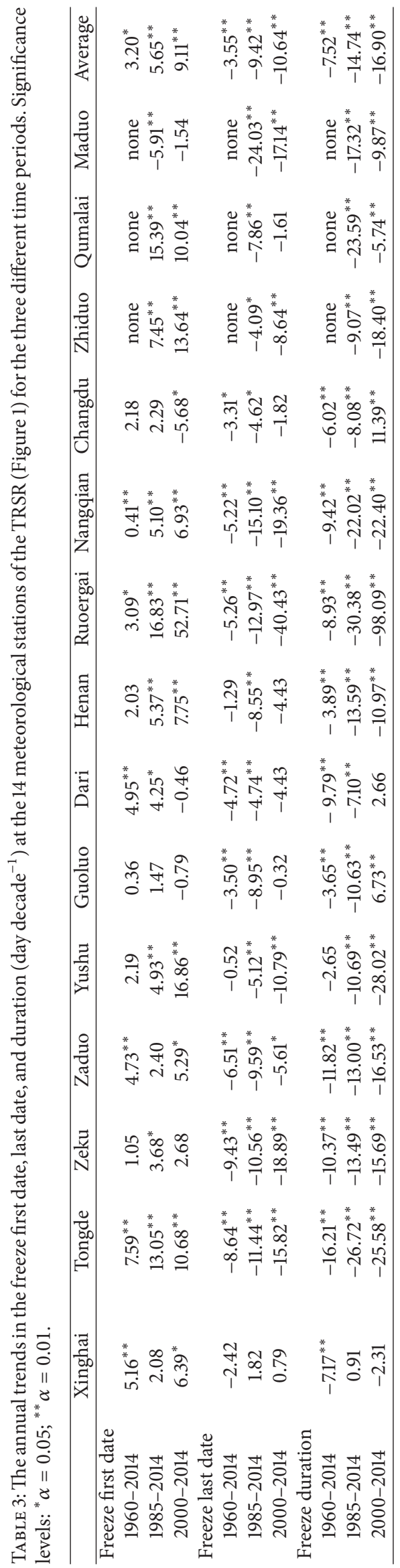




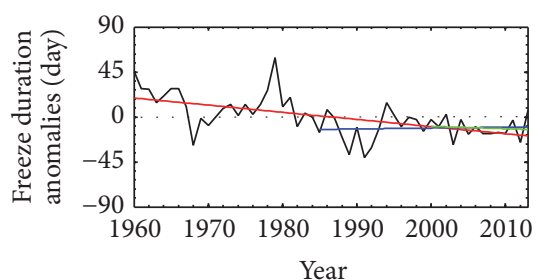

(a)

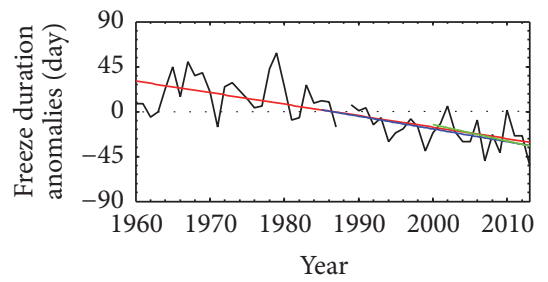

(d)

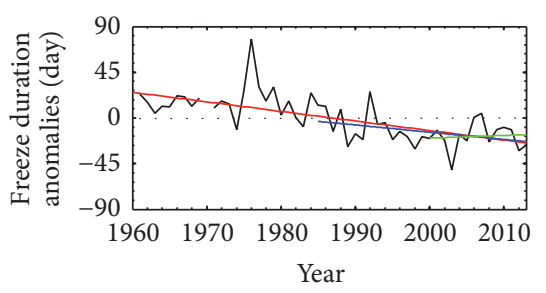

(g)

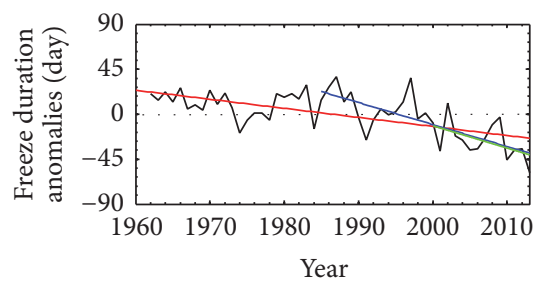

(j)

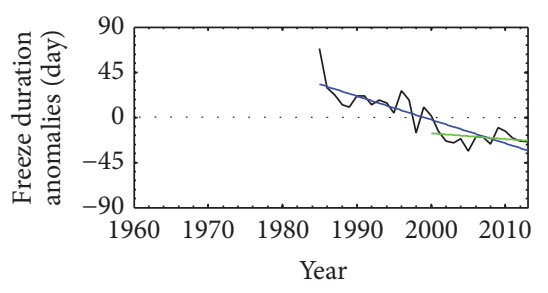

(m)

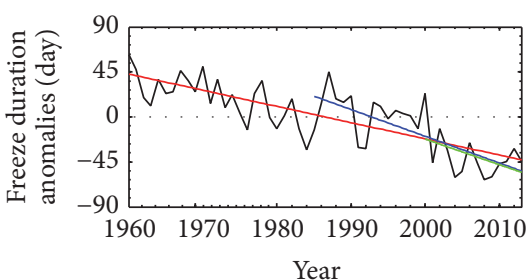

(b)

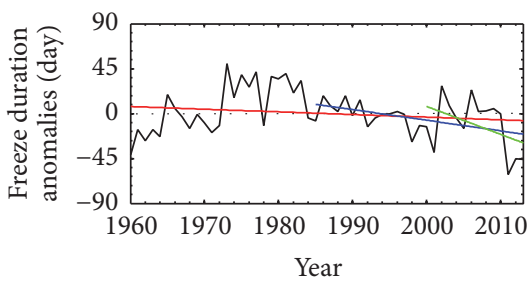

(e)

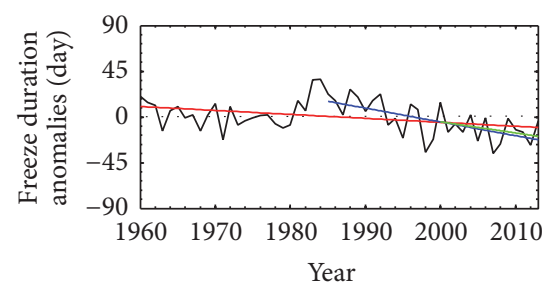

(h)

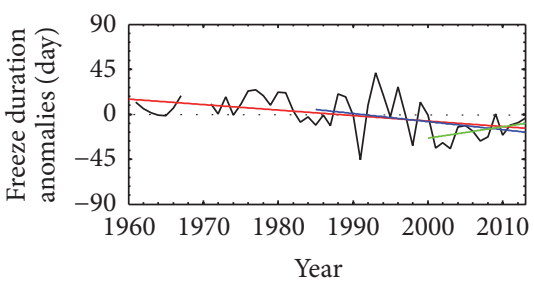

(k)

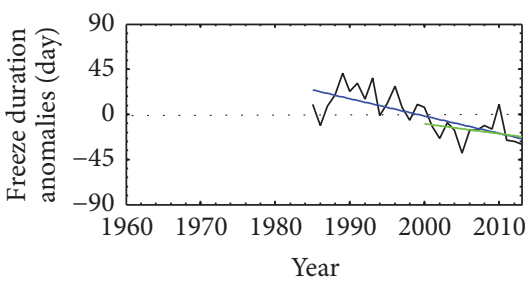

(n)

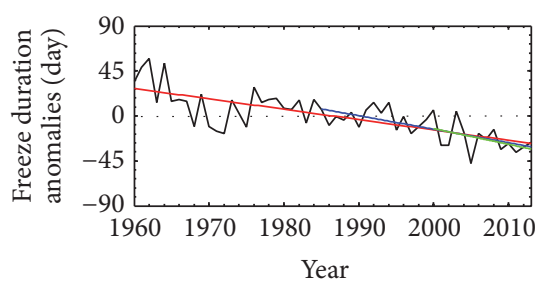

(c)

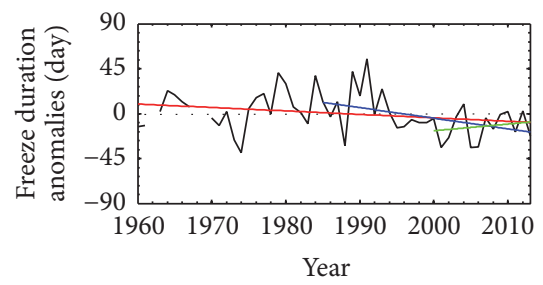

(f)

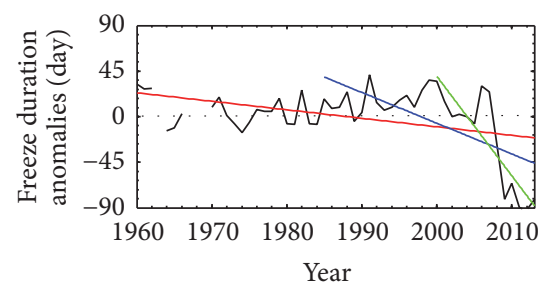

(i)

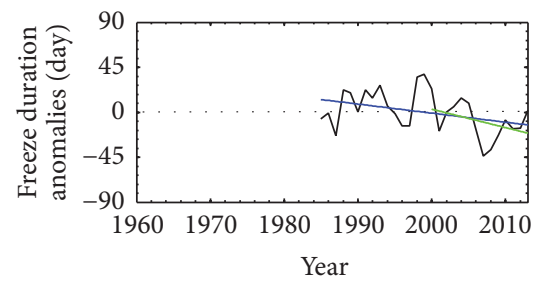

(1)

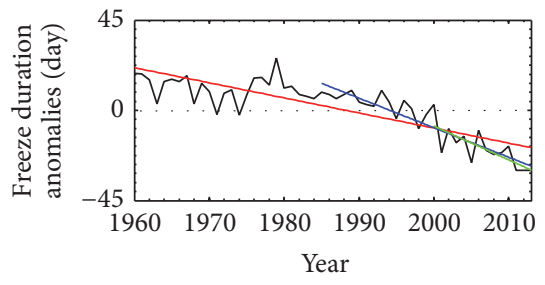

(o)

Figure 4: Freeze duration anomaly series during 1960-2014. Linear least squares regression lines are included for 1960-2014 (red line), 1985-2014 (blue line), and 2000-2014 (green line). (a) Xinghai station, (b) Tongde station, (c) Zeku station, (d) Zaduo station, (e) Yushu station, (f) Guoluo station, (g) Dari station, (h) Henan station, (i) Ruoergai station, (j) Nangqian station, (k) Changdu station, (l) Zhiduo station, (m) Qumalai station, (n) Maduo station, and (o) average.

consistent with the results of the modified Mann-Kendall trend (MMK) test and Sen's slope trends [4].

4.2. Relationship with the Forcing Variables. The relationships between the forcing variables with freeze depth, first date, last date, and duration for the three different time periods on the TRSR are provided in Table 5. The averaged time series that were related to forcing variables are shown in Figures 5, 6, 7, and 8 .
As shown in Table 5 and Figure 5, from 1960 to 2014, the freeze depth was significantly negatively correlated with air temperature, thawing index, freeze first date, and precipitation, but not with snow depth. The strongest relationship was a negative correlation with air temperature (at $\alpha=$ 0.01 ), which indicated that as mean annual air temperature increased, the freeze depth decreased. The second strongest correlation was thawing index, and this inverse relationship indicated that the longer the air temperatures remained above $0^{\circ} \mathrm{C}$, the lower the ground freeze was. The third strongest 
TABLE 4: The annual trends in air temperature, thawing index, maximum snow depth, annual precipitation, spring precipitation, summer precipitation, and autumn precipitation for three different time periods on the TRSR. Significance levels: ${ }^{*} \alpha=0.05 ;^{* *} \alpha=0.01$.

\begin{tabular}{lccc}
\hline & $1960-2014$ & $1985-2014$ & $2000-2014$ \\
\hline Air temperature $\left({ }^{\circ} \mathrm{C} /\right.$ decade $)$ & $0.30^{* *}$ & $0.62^{* *}$ & $3.60^{* *}$ \\
Thawing index $\left({ }^{\circ} \mathrm{C} \cdot\right.$ month/decade) & $1.56^{* *}$ & 0.54 & $3.83^{* *}$ \\
Maximum snow depth (cm/decade) & -0.05 & 19.38 & 0.57 \\
Annual precipitation (mm/decade) & 5.12 & 3.90 & $62.82^{*}$ \\
Spring precipitation (mm/decade) & $1.64^{* *}$ & 10.24 & $3.43^{*}$ \\
Summer precipitation (mm/decade) & 1.35 & 5.65 & 39.50 \\
Autumn precipitation (mm/decade) & 0.00 & 3.53 \\
\hline
\end{tabular}

TABLE 5: Correlation coefficients for freeze depth and forcing variables, freeze first date and forcing variables, freeze last date and forcing variables, and freeze duration and forcing variables for the three different time periods on the TRSR 9 stations (Figure 1). Significance levels: ${ }^{*} \alpha=0.05 ;{ }^{* *} \alpha=0.01$.

\begin{tabular}{|c|c|c|c|}
\hline & $1960-2014$ & 1985-2014 & $2000-2014$ \\
\hline \multicolumn{4}{|c|}{ Freeze depth and forcing variables } \\
\hline Air temperature & $-0.88^{* *}$ & $-0.89^{* *}$ & $-0.83^{* *}$ \\
\hline Thawing index & $-0.75^{* *}$ & $-0.78^{* *}$ & $-0.72^{* *}$ \\
\hline Maximum snow depth & 0.04 & 0.06 & -0.34 \\
\hline Annual precipitation & -0.15 & $-0.40^{*}$ & $-0.53^{*}$ \\
\hline Spring precipitation & $-0.27^{*}$ & -0.27 & -0.39 \\
\hline Summer precipitation & -0.08 & 0.30 & -0.39 \\
\hline Freeze first date & $-0.52^{* *}$ & $-0.60^{* *}$ & $-0.56^{*}$ \\
\hline \multicolumn{4}{|c|}{ Freeze first date and forcing variables } \\
\hline Air temperature & $0.68^{* *}$ & $0.70^{* *}$ & $0.54^{*}$ \\
\hline Thawing index & $0.68^{* *}$ & $0.70^{* *}$ & $0.59^{*}$ \\
\hline Annual precipitation & $0.28^{*}$ & 0.28 & 0.16 \\
\hline Autumn precipitation & $0.34^{* *}$ & $0.50^{* *}$ & 0.37 \\
\hline \multicolumn{4}{|c|}{ Freeze last date and forcing variables } \\
\hline Air temperature & $-0.85^{* *}$ & $-0.83^{* *}$ & $-0.64^{* *}$ \\
\hline Thawing index & $-0.81^{* *}$ & $-0.79^{* *}$ & -0.45 \\
\hline Maximum snow depth & 0.10 & 0.20 & -0.41 \\
\hline Annual precipitation & $-0.28^{*}$ & $-0.38^{*}$ & -0.40 \\
\hline Spring precipitation & $-0.41^{* *}$ & -0.32 & -0.50 \\
\hline Summer precipitation & -0.17 & -0.29 & -0.32 \\
\hline Freeze depth & $0.75^{* *}$ & $0.71^{* *}$ & $0.58^{*}$ \\
\hline \multicolumn{4}{|c|}{ Freeze duration and forcing variables } \\
\hline Air temperature & $-0.83^{* *}$ & $-0.83^{* *}$ & $-0.62^{*}$ \\
\hline Thawing index & $-0.80^{* *}$ & $-0.81^{* *}$ & $-0.52^{*}$ \\
\hline Maximum snow depth & 0.08 & 0.26 & -0.25 \\
\hline Annual precipitation & $-0.27^{*}$ & -0.33 & -0.27 \\
\hline Autumn precipitation & 0.01 & -0.20 & 0.277 \\
\hline Spring precipitation & $-0.41^{* *}$ & -0.28 & -0.44 \\
\hline Summer precipitation & -0.12 & -0.21 & -0.15 \\
\hline Freeze depth & $0.69^{* *}$ & $0.71^{* *}$ & $0.61^{*}$ \\
\hline
\end{tabular}

correlation was associated with freeze first date, and this inverse relationship indicated that a later soil freeze was associated with a thinner soil freeze depth. The freeze depth also displayed an inverse relationship with annual and spring precipitation, and the correlation became stronger over time.
From the data, the maximum freeze depth occurred in spring for most stations, except for individual stations where the maximum freeze depth occurred in winter and summer. In terms of the shallow layer soil, the soil moisture feedback mechanism revealed that an increase in soil moisture resulted 


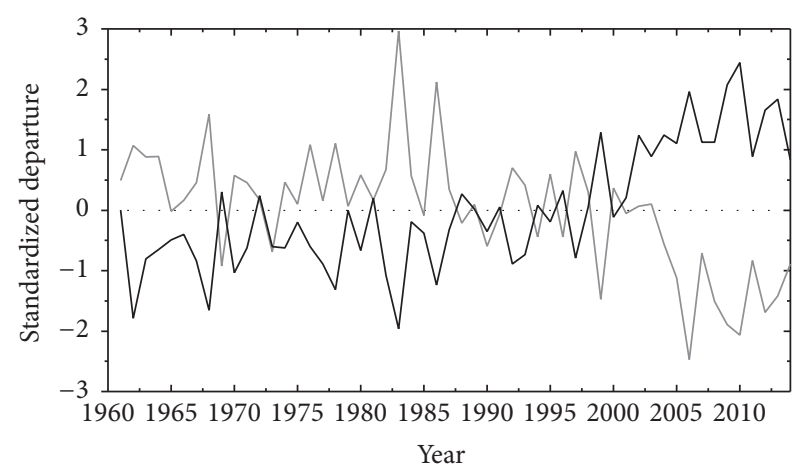

(a)

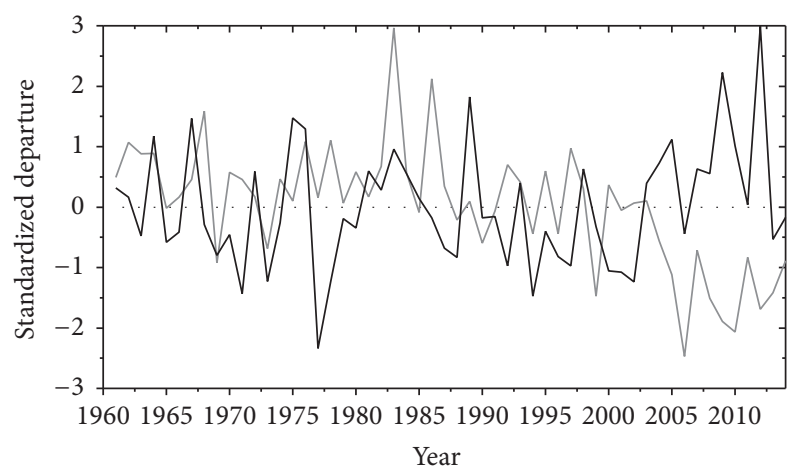

(c)

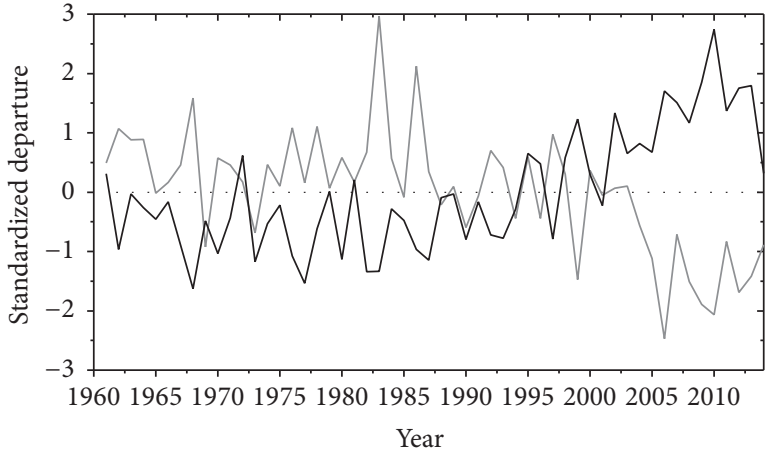

(b)

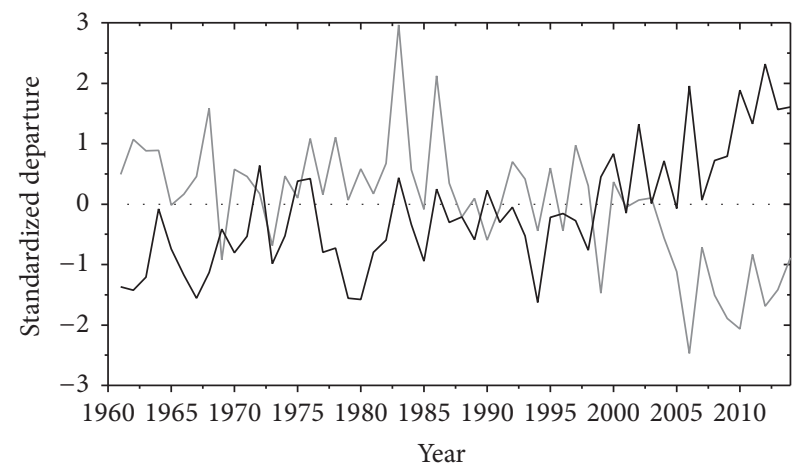

(d)

FIGURE 5: Time series of annual air temperature (a), thawing index (b), annual precipitation (c), and freeze first date (d) in TRSR (black line) with the time series of freeze depth (grey line). All variables were standardized with respect to their mean and standard deviation.

in an increase in evaporation rate, which resulted in energy being absorbed from the surrounding soil creating a decrease in soil temperature despite increased air temperature [46]. But for deep layer soil, an increase in soil moisture may be correlated with an increase in thawing rate, where energy is released to the surrounding soil as these temperatures were higher than that of the frozen soil, creating an increase in soil temperature [4]. This resulted in a significant negative relationship between freeze depth and soil moisture. From Table 5 it is evident that there was no correlation between freeze depth and snow depth, except during the last 15 years where a negative correlation was observed, but not obviously. This result is very different from the results obtained in Russia and North America, where temperature regime of frozen soil and the variation in the freeze depth was found to be significantly negatively correlated with snow depth $[1,22$, 27, 46]. As we know, in Russia and North America, stable snow covers have significant influence on the active layer due to its thermal insulation effect which can decrease radiative cooling. Consequently, the snow covers keep the soil warm and prevent the soil freeze. From the data, the maximum snow depth was very shallow on the TRSR compared with that in Russia and North America. This suggests that the snow did not remain on the ground for an extended period of time; thus the thermal insulation effect of snow would not have been significant. The effects of air temperature, thawing index, and soil moisture indicate that future changes in air temperature and precipitation may have a major influence on freeze depth. The decreasing trends in the freeze depth are expected to continue due to the increasing trends in air temperature and precipitation on the TRSR.

According to Table 5 and Figure 6, the freeze first date was positively correlated with air temperature, thawing index, annual precipitation, and autumn precipitation. The strong relationship (at $\alpha=0.05$ ) was correlations involving thawing index and air temperature, indicating that as air temperatures remained above $0^{\circ} \mathrm{C}$ for a period and mean annual air temperature increased, the freeze first date was delayed. The freeze first date also displayed a positive relationship with annual and autumn precipitation, indicating that the higher the ground soil moisture, the later the ground freeze. In autumn, the soil releases heat to the air resulting in a decrease in soil temperature. Wet soils have higher heat capacity than dry soils due to the heat capacity of water being much greater than the heat capacity of air. Consequently, wet soils slow the speed of temperature down and keep soil warm, and the freeze first date is delayed.

The freeze last date was negatively correlated with air temperature, thawing index, and precipitation and positively associated with freeze depth (Table 5 and Figure 7). Not surprisingly, air temperature and thawing index were also the strong external forcing variables. The third strongest correlation was associated with freeze depth, and this positive relationship indicated that the thinner the soil freeze is, the earlier the soil thawed. The freeze last date was also negatively associated with annual, spring, and summer precipitation, 


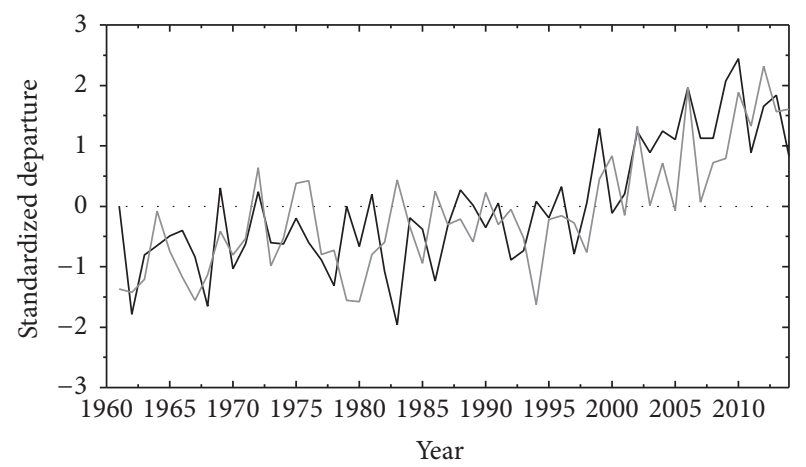

(a)

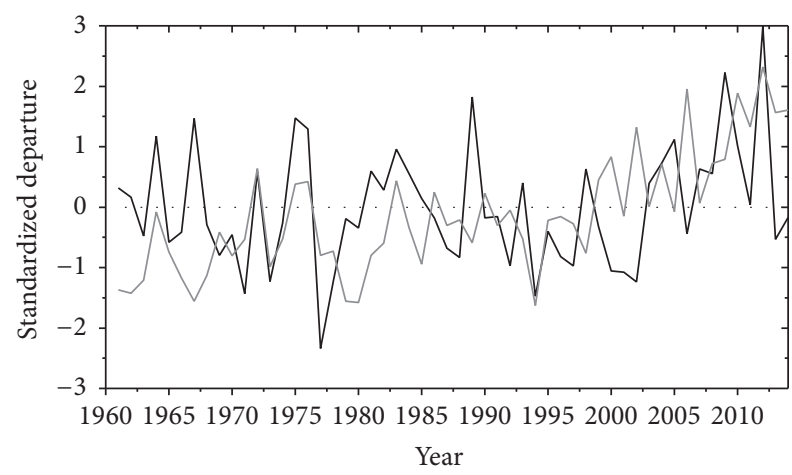

(c)

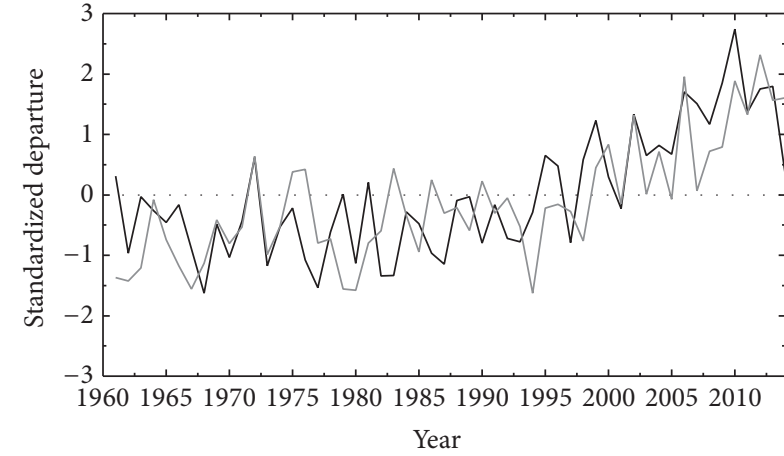

(b)

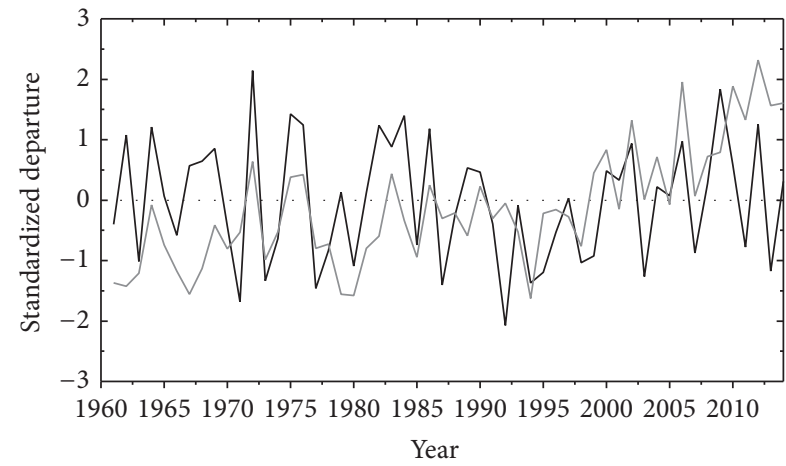

(d)

FIGURE 6: Time series of annual air temperature (a), thawing index (b), annual precipitation (c), and autumn precipitation (d) in TRSR (black line) with the time series of freeze first date (grey line). All variables were standardized with respect to their mean and standard deviation.

indicating that the higher the ground soil moisture content when the soil thawed is, the earlier the ground thawed. One possible explanation is that an increase in soil moisture may have resulted in an increase in thawing rate, releasing energy to the surrounding soil as a result of those temperatures being higher than that of the frozen soil, thus accelerating the soil thawing rate [4]. The freeze last date also had no obvious correlation with snow depth. There were some positive correlations with regard to the last 55 and 30 years, while a weak negative correlation was observed during the last 15 years.

During 1960-2014, the air temperature, thawing index, freeze depth, and annual precipitation had a clear and significant effect on freeze duration, with negative correlations in air temperature, thawing index, and annual precipitation and positive correlations in freeze depth (Table 5 and Figure 8). Furthermore, the relationship between snow depth and freeze duration exhibited less correlation over the past 55 years. The decreasing trends in the freeze duration were expected to continue with the increasing air temperature and precipitation and with the decreasing freeze depth on the TRSR.

Additionally, the interactions of vegetation and soil characteristics are very complex. Studies have shown that vegetation has an important effect on the thaw depth of permafrost $[23,26]$. As shown in Figure 2, vegetation in this area is typical alpine meadow $[47,48]$ and has decreased in the region since $1980[49,50]$. Less vegetation may have influenced the soil moisture distribution and indirectly affected the freeze depth and freeze duration. However, the vegetation changes in the meteorological observation field were still not clear. Further research is needed to determine the interactions between vegetation and frozen soil in this region.

\section{Conclusion}

A continuous, accelerated decreasing trend in freeze depth occurred in the TRSR during the 1985-2014 and 2000-2014 periods, compared with that during the 1960-2014 periods. The rates of decrease were $-3.98 \mathrm{~cm}$ decade ${ }^{-1}$ over the past 55 years, $-8.93 \mathrm{~cm}$ decade ${ }^{-1}$ over the past 30 years, and $-13.98 \mathrm{~cm}$ decade $^{-1}$ over the past 15 years. The net change was a $21.89 \mathrm{~cm}$ decrease in freeze depth in 2014 compared to 1955 and an even greater $26.79 \mathrm{~cm}$ decrease from 1985 to 2014 . A decrease of $20.97 \mathrm{~cm}$ was observed over the past 15 years.

The freeze first date has been delayed, while the freeze last date has been advanced significantly over the past 55 years. The advanced trends in freeze last date were more significant than the delayed trends in freeze first date across all three study periods. The freeze duration also experienced an accelerated decrease during the 1960-2014, 1985-2014, and 2000-2014 periods. The rate of decrease was -7.52 days decade $^{-1}$ over the past 55 years, -14.74 days decade ${ }^{-1}$ over the past 30 years, and -16.90 days decade ${ }^{-1}$ over the past 15 years. The net change was a 41.36-day decrease in freezing duration in 2014 compared to 1955 and an even greater 44.22-day 


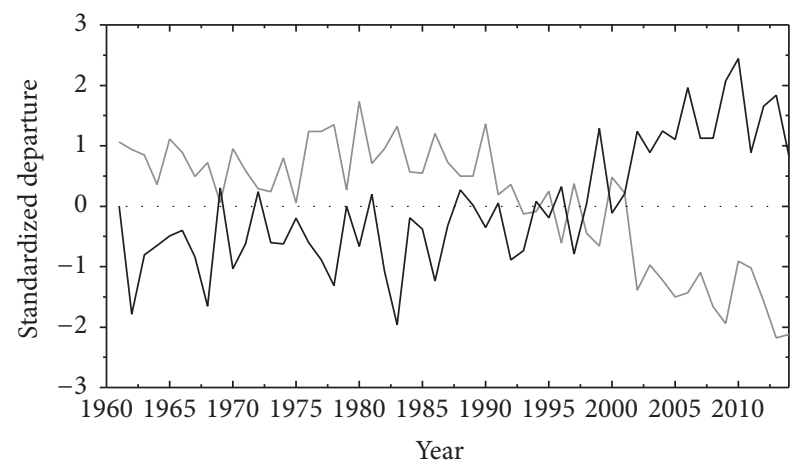

(a)

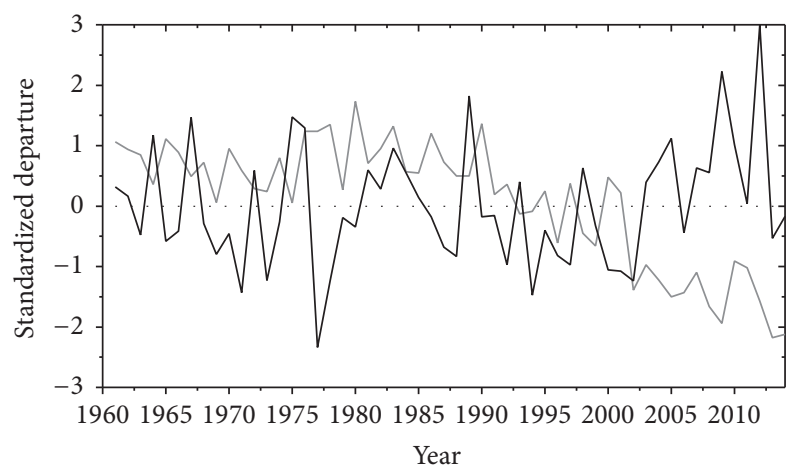

(c)

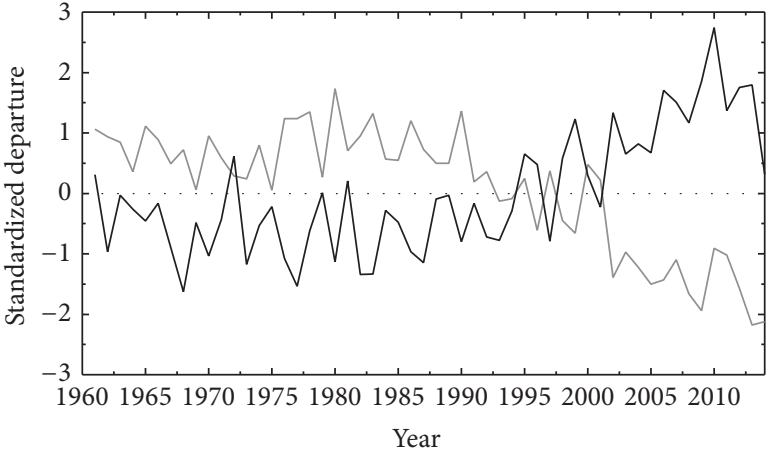

(b)

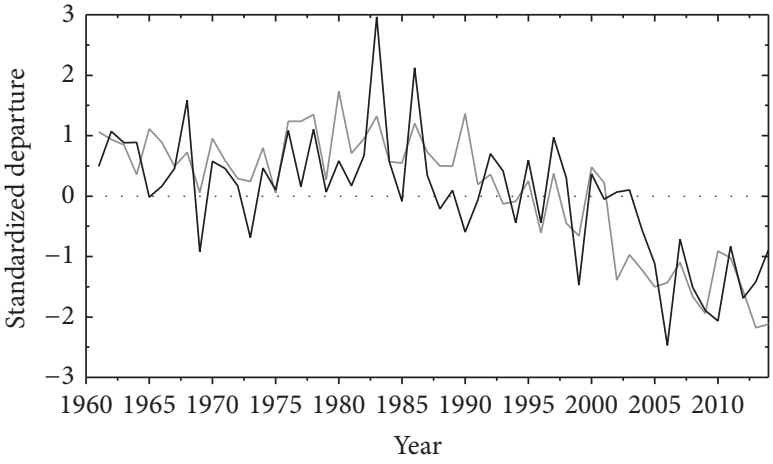

(d)

FIGURE 7: Time series of annual air temperature (a), thawing index (b), annual precipitation (c), and freeze depth (d) in TRSR (black line) with the time series of freeze last date (grey line). All variables were standardized with respect to their mean and standard deviation.

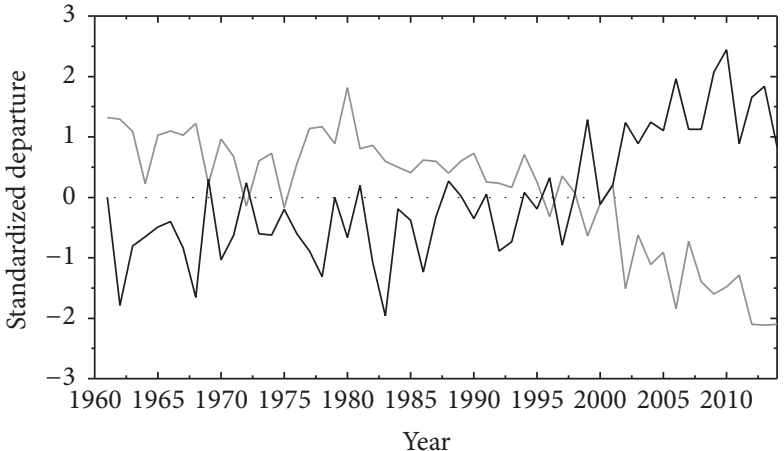

(a)

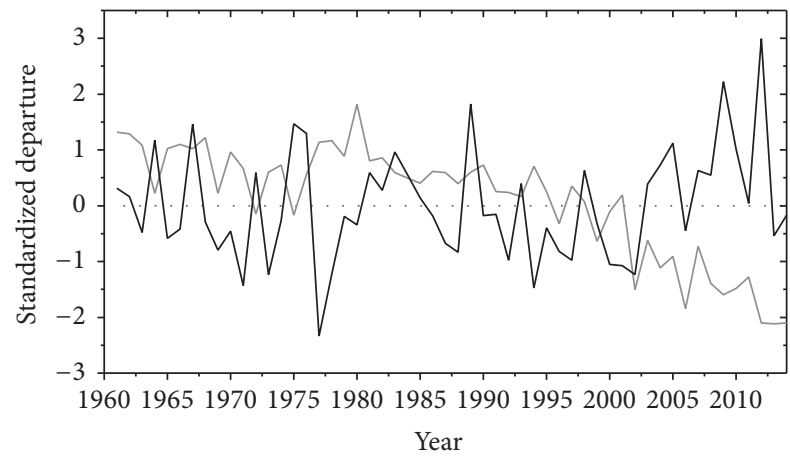

(c)

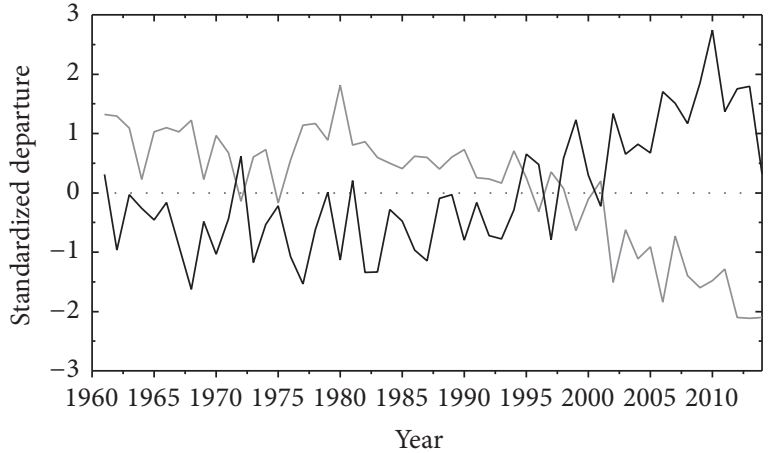

(b)

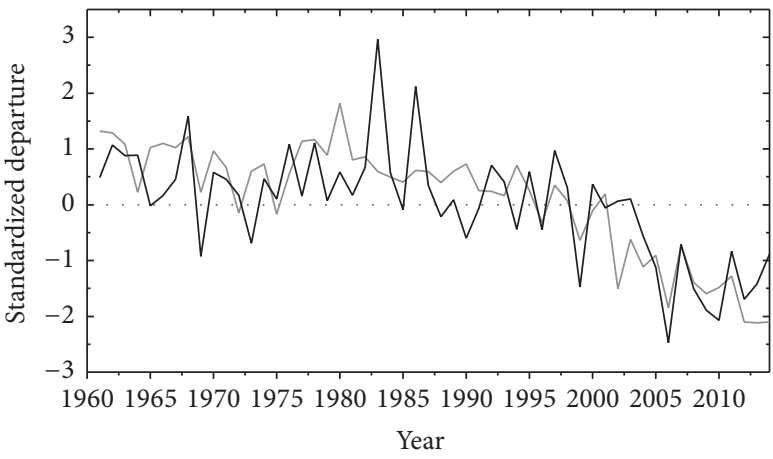

(d)

FIGURE 8: Time series of annual air temperature (a), thawing index (b), annual precipitation (c), and freeze depth (d) in TRSR (black line) with the time series of freeze duration (grey line). All variables were standardized with respect to their mean and standard deviation. 
decrease from 1985 to 2014, while it was a 25.35-day decrease over the past 15 years.

The freeze depth and period were strongly affected by air temperature, thawing index, and soil moisture (precipitation), but not by snow. The freeze depth, freeze first date, freeze last date, and freeze duration also influenced each other. The freeze depth was significantly negatively correlated with air temperature, thawing index, freeze first date, and precipitation. The freeze first date was positively correlated with air temperature, thawing index, annual precipitation, and autumn precipitation. The air temperature, thawing index, freeze depth, and annual precipitation had a clear and significant effect on freeze duration, with negative correlations observed with regard to air temperature, thawing index, and annual precipitation and positive correlations associated with freeze depth. The decreasing trends in freeze depth and duration are expected to continue as a result of increasing trends in air temperature and precipitation on the TRSR.

\section{Conflicts of Interest}

The authors declare that they have no conflicts of interest.

\section{Acknowledgments}

This work was supported by the National Natural Science Foundation of China (nos. 91537104, 41375077, and 91537214).

\section{References}

[1] B. Qian, E. G. Gregorich, S. Gameda, D. W. Hopkins, and X. L. Wang, "Observed soil temperature trends associated with climate change in Canada," Journal of Geophysical Research, vol. 116, no. 2, 2011.

[2] E. Yeşilirmak, "Soil temperature trends in Büyük Menderes Basin, Turkey," Meteorological Applications, vol. 21, no. 4, pp. 859-866, 2014.

[3] Q. Hu and S. Feng, "How have soil temperatures been affected by the surface temperature and precipitation in the Eurasian continent?" Geophysical Research Letters, vol. 32, no. 14, pp. 1-4, 2005.

[4] S. Luo, X. Fang, S. Lyu et al., "Frozen ground temperature trends associated with climate change in the Tibetan Plateau Three River Source Region from 1980 to 2014," Climate Research, vol. 67, no. 3, pp. 241-255, 2016.

[5] L. Zhao, Q. Wu, S. S. Marchenko, and N. Sharkhuu, "Thermal state of permafrost and active layer in central Asia during the international polar year," Permafrost and Periglacial Processes, vol. 21, no. 2, pp. 198-207, 2010.

[6] O. W. Frauenfeld, T. Zhang, and J. L. McCreight, "Northern hemisphere freezing/thawing index variations over the twentieth century," International Journal of Climatology, vol. 27, no. 1, pp. 47-63, 2007.

[7] D. Guo and H. Wang, "Simulation of permafrost and seasonally frozen ground conditions on the Tibetan Plateau, 1981-2010," Journal of Geophysical Research Atmospheres, vol. 118, no. 11, pp. 5216-5230, 2013.

[8] D. M. Lawrence, A. G. Slater, and S. C. Swenson, "Simulation of present-day and future permafrost and seasonally frozen ground conditions in CCSM4," Journal of Climate, vol. 25, no. 7, pp. 2207-2225, 2012.

[9] Q. Wu, T. Zhang, and Y. Liu, “Thermal state of the active layer and permafrost along the Qinghai-Xizang (Tibet) railway from 2006 to 2010," The Cryosphere, vol. 6, no. 3, pp. 607-612, 2012.

[10] G. Cheng and H. Jin, "Permafrost and groundwater on the Qinghai-Tibet Plateau and in northeast China," Hydrogeology Journal, vol. 21, no. 1, pp. 5-23, 2013.

[11] C. Harris, L. U. Arenson, H. H. Christiansen et al., "Permafrost and climate in Europe: monitoring and modelling thermal, geomorphological and geotechnical responses," Earth-Science Reviews, vol. 92, no. 3-4, pp. 117-171, 2009.

[12] R. Li, L. Zhao, Y. Ding et al., "Temporal and spatial variations of the active layer along the Qinghai-Tibet Highway in a permafrost region," Chinese Science Bulletin, vol. 57, no. 35, pp. 4609-4616, 2012.

[13] F.-S. Chapin III, M. Sturm, M. C. Serreze et al., "Role of landsurface changes in arctic summer warming," Science, vol. 310, no. 5748, pp. 657-660, 2005.

[14] R. G. Pearson, S. J. Phillips, M. M. Loranty et al., "Shifts in Arctic vegetation and associated feedbacks under climate change," Nature Climate Change, vol. 3, no. 7, pp. 673-677, 2013.

[15] X. Xue, J. Guo, B. Han, Q. Sun, and L. Liu, "The effect of climate warming and permafrost thaw on desertification in the Qinghai-Tibetan Plateau," Geomorphology, vol. 108, no. 3-4, pp. 182-190, 2009.

[16] F. E. Nelson, “(Un)frozen in time,” Science, vol. 299, no. 5613, pp. $1673-1675,2003$.

[17] E. A. Davidson and I. A. Janssens, "Temperature sensitivity of soil carbon decomposition and feedbacks to climate change," Nature, vol. 440, no. 7081, pp. 165-173, 2006.

[18] B. L. Kurylyk, K. T. B. MacQuarrie, and J. M. McKenzie, "Climate change impacts on groundwater and soil temperatures in cold and temperate regions: implications, mathematical theory, and emerging simulation tools," Earth-Science Reviews, vol. 138, pp. 313-334, 2014.

[19] B. Chen, S. Luo, S. Lü, Y. Zhang, and D. Ma, "Effects of the soil freeze-thaw process on the regional climate of the QinghaiTibet Plateau," Climate Research, vol. 59, no. 3, pp. 243-257, 2014.

[20] S.-Q. Luo, S.-H. Lü, Y. Zhang et al., "Soil thermal conductivity parameterization establishment and application in numerical model of central Tibetan Plateau," Chinese Journal of Geophysics (Acta Geophysica Sinica), vol. 52, no. 4, pp. 919-928, 2009.

[21] S. Luo, S. Lü, and Y. Zhang, "Development and validation of the frozen soil parameterization scheme in Common Land Model," Cold Regions Science and Technology, vol. 55, no. 1, pp. 130-140, 2009.

[22] T. Zhang, O. W. Frauenfeld, M. C. Serreze et al., "Spatial and temporal variability in active layer thickness over the Russian Arctic drainage basin," Journal of Geophysical Research D: Atmospheres, vol. 110, no. 16, 2005.

[23] K. Narita, K. Harada, K. Saito, Y. Sawada, M. Fukuda, and S. Tsuyuzaki, "Vegetation and permafrost thaw depth 10 years after a Tundra fire in 2002, Seward Peninsula, Alaska," Arctic, Antarctic, and Alpine Research, vol. 47, no. 3, pp. 547-559, 2015.

[24] D. Guo and H. Wang, "Simulated change in the near-surface soil freeze/thaw cycle on the Tibetan Plateau from 1981 to 2010," Chinese Science Bulletin, vol. 59, no. 20, pp. 2439-2448, 2014.

[25] K. Wang, T. Zhang, and X. Zhong, "Changes in the timing and duration of the near-surface soil freeze/thaw status from 1956 to 2006 across China," The Cryosphere, vol. 9, no. 3, pp. 1321-1331, 2015. 
[26] J. P. Fisher, C. Estop-Aragonés, A. Thierry et al., "The influence of vegetation and soil characteristics on active-layer thickness of permafrost soils in boreal forest," Global Change Biology, vol. 22, no. 9, pp. 3127-3140, 2016.

[27] O. W. Frauenfeld, T. Zhang, R. G. Barry, and D. Gilichinsky, "Interdecadal changes in seasonal freeze and thaw depths in Russia," Journal of Geophysical Research D: Atmospheres, vol. 109, no. 5, pp. D05101-D05112, 2004.

[28] A. Anandhi, S. Perumal, P. H. Gowda et al., "Long-term spatial and temporal trends in frost indices in Kansas, USA," Climatic Change, vol. 120, no. 1-2, pp. 169-181, 2013.

[29] X. Li, R. Jin, X. Pan, T. Zhang, and J. Guo, "Changes in the near-surface soil freeze-thaw cycle on the Qinghai-Tibetan Plateau," International Journal of Applied Earth Observation and Geoinformation, vol. 17, no. 1, pp. 33-42, 2012.

[30] H. Jin, R. He, G. Cheng et al., "Changes in frozen ground in the source area of the Yellow River on the Qinghai-Tibet Plateau, China, and their eco-environmental impacts," Environmental Research Letters, vol. 4, no. 4, Article ID 045206, 2009.

[31] L. Gu, J. Yao, Z. Hu, and L. Zhao, "Comparison of the surface energy budget between regions of seasonally frozen ground and permafrost on the Tibetan Plateau," Atmospheric Research, vol. 153, pp. 553-564, 2015.

[32] Q. You, J. Min, H. Lin, N. Pepin, M. Sillanpää, and S. Kang, "Observed climatology and trend in relative humidity in the central and eastern Tibetan Plateau," Journal of Geophysical Research: Atmospheres, vol. 120, no. 9, pp. 3610-3621, 2015.

[33] X. Yi, Y. Yin, G. Li, and J. Peng, “Temperature variation in recent 50 years in the Three-River Headwaters Region of Qinghai Province," Acta Geographica Sinica, vol. 66, no. 11, pp. 1451-1465, 2011.

[34] W. Xu, S. Gu, W. Su, S. Jiang, R. Xiao, and J. Xiao, "Spatial pattern and its variations of aridity/humidity during 1971-2010 in Three River Source Region on the Qinghai Tibet Plateau," Arid Land Geography, vol. 35, pp. 46-55, 2012.

[35] L. Liang, L. Li, C. Liu, and L. Cuo, "Climate change in the Tibetan plateau three rivers source region: 1960-2009," International Journal of Climatology, vol. 33, no. 13, pp. 2900-2916, 2013.

[36] Q. You, S. Kang, C. Li, Y. Yan, and S. Yan, "Change in extreme temperature over San Jiang Yuan region in the period from 1961 to 2005," Resources and Environment in the Yangtze Basin, vol. 17, pp. 232-236, 2008.

[37] G. Y. Ren, M. Z. Xu, Z. Y. Chu, J. Guo, Q. X. Li, and X. N. Liu, "Changes of surface air temperature in China during 19512004," Climatic and Environmental Research, vol. 10, 2005.

[38] L. Zhong, Z. Su, Y. Ma, M. S. Salama, and J. A. Sobrino, "Accelerated changes of environmental conditions on the Tibetan Plateau caused by climate change," Journal of Climate, vol. 24, no. 24, pp. 6540-6550, 2011.

[39] A. Duan and Z. Xiao, "Does the climate warming hiatus exist over the Tibetan Plateau?" Scientific Reports, vol. 5, article 13711, 2015.

[40] X. Liu and B. Chen, "Climatic warming in the Tibetan Plateau during recent decades," International Journal of Climatology, vol. 20, no. 14, pp. 1729-1742, 2000.

[41] J. Yang, Y. Ding, S. Liu, and C. Tan, "Vulnerability of mountain glaciers in China to climate change," Advances in Climate Change Research, vol. 6, no. 3-4, pp. 171-180, 2015.

[42] CMA, Specifications for Surface Meteorological Observation, China Meteorological Press, Beijing, China, 2003.
[43] B. Chen and J. Li, "Characteristics of spatial and temporal variation of seasonal and short-term frozen soil in China in recent 50 years," Chinese Journal of Atmospheric Sciences, vol. 32, pp. 432-443, 2008.

[44] R. Gao, W. Dong, and Z. Wei, “The features of temporal and spatial distributions of seasonal frozen soil in the Tibetan Plateau," Journal of Glaciology and Geocryology, vol. 30, pp. 740744, 2008.

[45] F. Wei, Modern Climatic Statistical Diagnosis and Prediction Technology, China Meteorological Press, Beijing, China, 2nd edition, 2007.

[46] T. Zhang, R. G. Barry, D. Gilichinsky, S. S. Bykhovets, V. A. Sorokovikov, and J. Ye, "An amplified signal of climatic change in soil temperatures during the last century at Irkutsk, Russia," Climatic Change, vol. 49, no. 1-2, pp. 41-76, 2001.

[47] L. Shang, Y. Zhang, S. Lü, and S. Wang, "Energy exchange of an alpine grassland on the eastern Qinghai-Tibetan Plateau," Science Bulletin, vol. 60, no. 4, pp. 435-446, 2015.

[48] Z. Li, S. Lyu, Y. Ao, L. Wen, L. Zhao, and S. Wang, "Longterm energy flux and radiation balance observations over Lake Ngoring, Tibetan Plateau," Atmospheric Research, vol. 155, pp. 13-25, 2015.

[49] G. Wang, Y. Li, and Y. Wang, Processes and Environmental Changes River Headwater Regions of Tibetan Plateau, Science Press, Beijing, China, 2010.

[50] R. Li, Vegetation Changes and Responses to Climate Change over the Tibetan Plateau, University of Chinese Academy of Sciences, Beijing, China, 2015. 

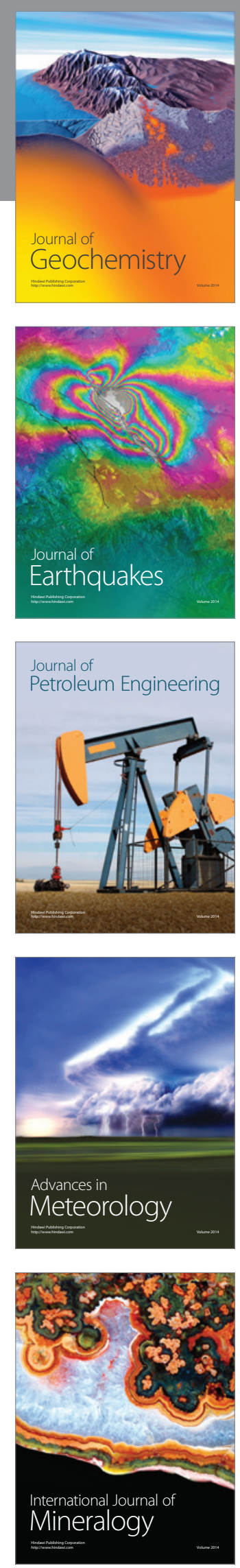
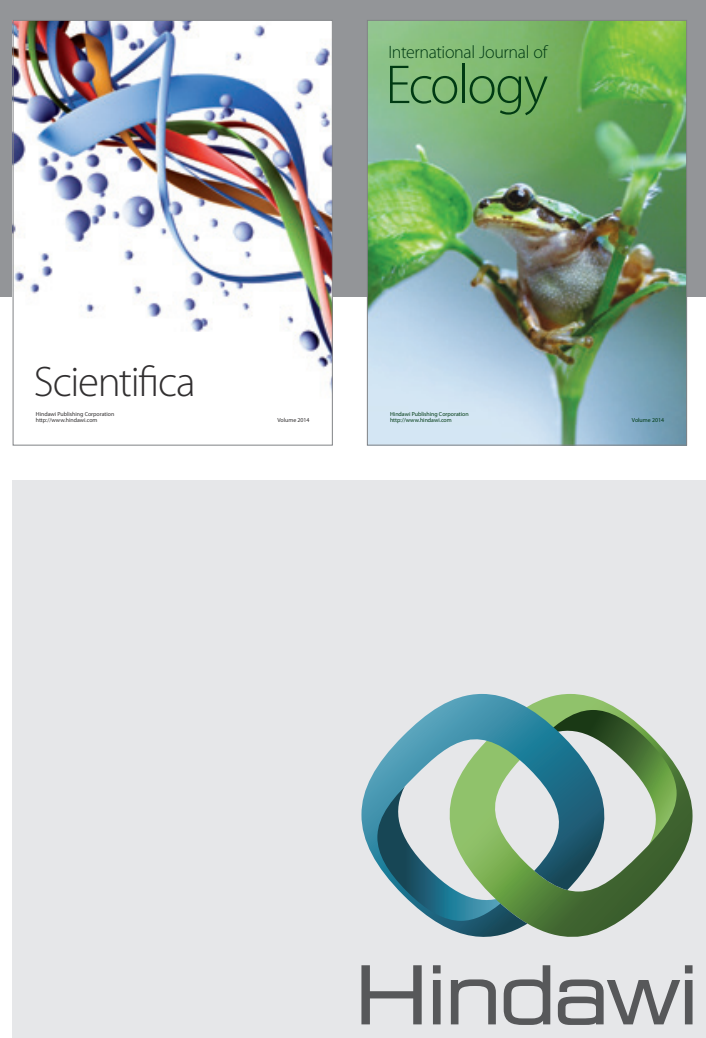

Submit your manuscripts at

https://www.hindawi.com
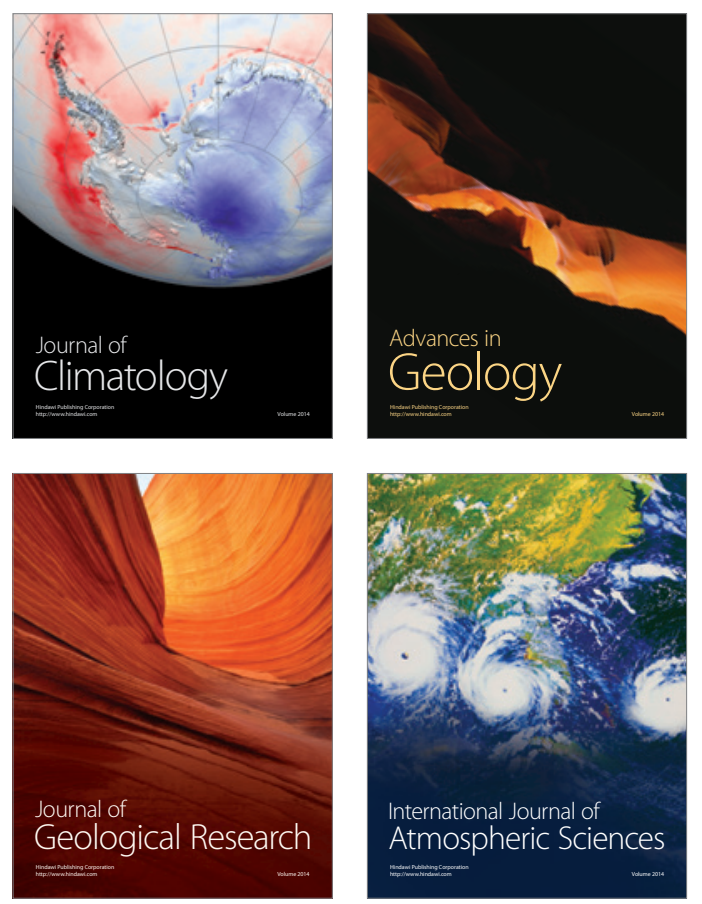

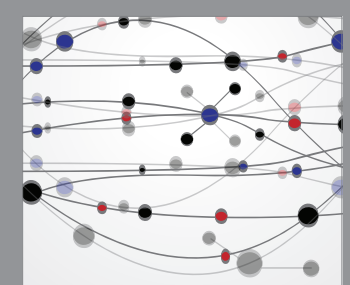

The Scientific

\section{World Journal}
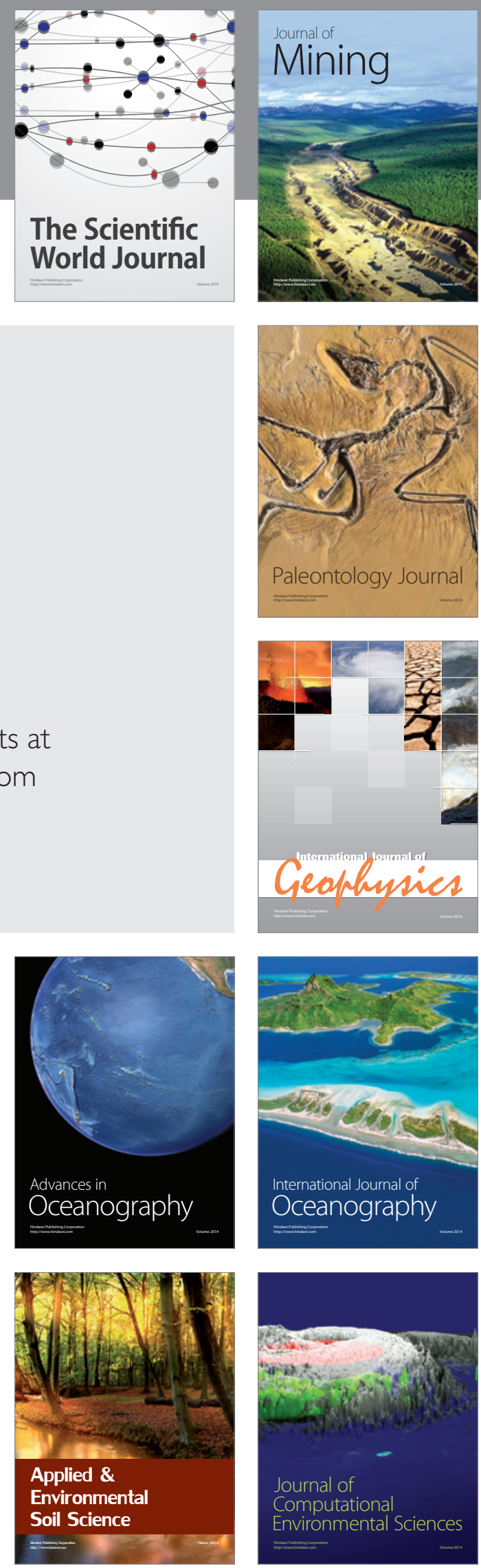